\title{
Leaf spot disease of coconut seedling and its eco-friendly management
}

\author{
M. A. H. Khan ${ }^{1^{*}}$ and I. Hossain ${ }^{2}$ \\ ${ }^{1}$ Bangladesh Agricultural Research Institute, Joydebpur, Gazipur and ${ }^{2}$ Department of Plant Pathology, Bangladesh \\ Agricultural University, Mymensingh-2202, Bangladesh, *E-mail: helim1367@yahoo.com
}

\begin{abstract}
The effect of weather on prevalence of seedling diseases of coconut during 2010-11 and 2011-12 in different areas of Bangladesh was studied to develop an environment friendly disease management practice. Pestalotia palmarum was isolated and identified from leaf having spot. Incidence and severity of grey leaf spot at seedling stage were determined and significant variations were observed depending on weather factors as well as locations. Occurrence of seedling disease was significantly influenced by temperature, rainfall and relative humidity. Comparative effectiveness of BAU-Biofungicide either alone or in combination with two fungicides viz. Bavistin or Dithane M-45 was evaluated on coconut seedling in the nursery. Among the treatments applied, Trichoderma harzianum based BAU-Biofungicide either alone or in combination with Bavistin (0.2\%) as an excellent biocontrol means in controlling leaf spot disease of coconut.
\end{abstract}

Keywords: Coconut seedling, Leaf spot disease, BAU-Biofungicide, Eco-friendly management

\section{Introduction}

Coconut (Coccos nucifera) is one of the most important fruits in Bangladesh. It provides coconut oil, coconut milk as well as mineral enriched water that widely used in the country. Coconut contributes a great share of the total production of fruits in the country. About $80 \%$ of families in the country consume less than the minimum recommended daily requirement of fruits. As a consequence widespread nutritional deficiencies in vitamin ' $A$ ', ' $C$ ', iron and other nutrients cause debilitating illness among the population (HKI, 2005).

The horticultural crops, especially fruits are playing a vital role in crop diversification, nutrition, economy and environment of the country. Improved varieties of fruits like mango, guava litchi, jackfruit, ber, coconut etc. are available in Bangladesh which can contribute in the poverty ridden economy and nutrition significantly (Rahim, 2009). However, the availability of Quality Planting Materials (QPM) is inadequate. Success of an orchard or homestead gardening depends on the quality of the planting material. The first and most important step is to supply farmers with seedlings that are free of diseases.

Determining the effect of temperature, rainfall and relative humidity on the formation, release and germination of inocula in different pathosystems have been focused by many researchers worldwide (Sutton, 1981; Pinkerton et. al., 1998; MacHardy et. al., 2001; Mondal \& Timmer, 2002). Based on understanding the disease epidemiology, effective control measures could be developed and implemented (Hopkins and McQuilken, 2000). Disease of fruits species have been reviewed by many workers throughout the world. Plant diseases play a major role in reducing yields of horticultural crops in the tropics (Pathak, 1980; Rawal, 1990; Ploetz et. al., 1998; Mariau, 2001). It has been estimated that the production could be increased at least by $28 \%$ if the crop could be protected against various seedling diseases and many of these diseases have been reported that transmitted through the planting materials (Rawal, 1990).

Coconut is grown widely in Bangladesh. However, seedling diseases of coconut have not been thoroughly investigated in Bangladesh. Ghose (2000) found that coconut mainly suffered from grey leaf spot or blight caused by (Pestalotiopsis palmarum) and bud rot caused by Phytophthora palmivora in 22 countries and described distribution, alternative hosts, epidemiology, varietal reaction and management of the disease. He also reported that grey leaf spot or blight caused by Pestalotiopsis palmarum had no immune or resistant sources against the disease. Little information is available about the incidence, prevalence, epidemiology and management of seedling diseases of coconut in Bangladesh. Therefore, it 
is imperative to investigate nurseries to get information on the incidence, severity, epidemiology and management of the pathogen that cause seedling leaf spot disease. This experiment was, therefore, undertaken to investigate the effects of temperature, rainfall and humidity on the leaf spot disease of coconut in Jessore, Jhenaidah and Faridpur and to suggest an eco-friendly management package for the disease.

\section{Materials and Methods}

Altogether 15 nurseries in three districts of Bangladesh viz. Faridpur, Jhenaidah and Jessore were surveyed and leaf spot disease of coconut seedlings were studied and information were recorded. Four visits were made in each year in the selected 15 nurseries during 2010-2012 growing season of one to two years old seedlings. During the survey in coconut nurseries, total number of coconut seedlings found in the nurseries was recorded. Total numbers of seedlings, number of healthy and diseased seedlings were counted from the selected nurseries. Then 30 seedlings were selected randomly from each of the selected nurseries. Each seedling was observed carefully and disease symptoms were recorded following the description of Singh (1996), Singh (1998) and Pathak (1980). Disease incidence was assessed as percentage of plants infected with at least one leaf spot or visible symptom. Assessment of disease incidence of coconut seedlings was calculated using formula of Rai and Mamatha (2005). Disease severity was evaluated using the method of Fagan and Goes (1999). The scale was used from 0 to 5 , where $0=$ No visible symptoms, $1=1-5 \%$ leaf area diseased, $2=5.1-12 \%$ leaf area diseased, 3=12.1-25\% leaf area diseased, $4=25.1-50 \%$ leaf area diseased and $5=>50 \%$ leaf area diseased. Moreover, data on air temperature, relative humidity and rainfall were recorded.

Eco-friendly management trial was conducted at Bangladesh Agricultural University, Mymensingh during August, 2010 to September, 2012. Pits were prepared in the field as per method of Mondal (2000). Application of fertilizers and manures were done following BARC fertilizer Recommendation Guide (FRG, 2005). The experiment was laid out in Randomized Completely Block Design (RCBD) with three replications and 15 seedlings per treatment were used. For the management of nursery diseases of coconut seven different treatments were evaluated. Two fungicides viz. Bavistin and Dithane M-45, and one Trichoderma based preparation known as BAU-Biofungicide were used. The fungicides were applied as foliar spray at 30 days interval, but BAU-Biofungicide was applied as foliar spray as well as drenching in the soil. The treatments were as $T_{1}=$ BAU-Biofungicide applied as soil drenching @ $2 \%, T_{2}=B A U$ Biofungicide applied as foliar spray @ 2\%, $\mathrm{T}_{3}=$ BAU-Biofungicide applied as soil drenching and foliar spray @ 2\% and 2\%, respectively, $\mathrm{T}_{4}=$ Bavistin as foliar spray@ 0.2\%, $\mathrm{T}_{5}=$ Dithane $\mathrm{M}-45$ as foliar spray @ $0.2 \%, \mathrm{~T}_{6}=\mathrm{BAU}-$ Biofungicide applied as soil drenching and Bavistin as foliar spray @ 2\% and 0.2\%, respectively and $\mathrm{T}_{7}=$ Untreated control. BAU-Biofungicide is a formulated product of Trichoderma harzianum, developed in Eco-friendly Disease Management Laboratory, Department of Plant Pathology, Bangladesh Agricultural University, Mymensingh (Hossain, 2003). BAU- Biofungicide was thoroughly mixed with the soil @ $6.4 \mathrm{~g} / \mathrm{m}^{2}$ soil (Lo et al., 1996). The data on different parameters were compiled and analyzed statistically with the computer software program MSTAT-C (Russell, 1986). The mean differences were adjudged by Duncan's Multiple Range Test (Gomez and Gomez, 1984).

\section{Results and Discussion}

Investigation on seedling diseases of coconut in different nurseries of Jessore, Jhenaidah and Faridpur during 2010-2011 and 2011-2012 revealed that leaf spot was the most common disease in the nurseries. The leaf spot causal pathogen was identified as Pestalotia palmarum. Incidence of leaf spot disease in coconut seedlings varied significantly from season to season as well as location to location that ranged from 26.33 to $80.36 \%$ in $2010-2011$ and 24.89 to $74.35 \%$ in 2011-2012, respectively (Table 1). The highest incidence (80.36\%) of leaf spot was observed in October, 2010 at Faridpur followed by April, 2011 at Faridpur and the lowest (26.33 \%) was observed in January, 2011 at Jessore. The similar trend was found in 2011-2012. The severity of leaf spot varied significantly from season to season as well as location to location and that ranged from 18.44 to $40.67 \%$ in $2010-2011$ and 15.73 to $27.67 \%$ in 2011 2012, respectively (Table 1). The highest severity (40.67\%) was observed in October, 2010 followed by 
April, 2011 at Faridpur but they were statistically at par. The lowest severity (18.44\%) was recorded in January, 2011 at Faridpur in 2010-2011. In 2011-2012 the highest severity (27.67\%) was recorded in October, 2011 at Jessore and the lowest (15.73 \%) was recorded in January, 2012 at Faridpur but they were statistically insignificant.

Table 1. Incidence and severity of leaf spot disease of coconut seedling in different locations during July 2010 to April 2011 and July 2011 to April 2012 of Bangladesh

\begin{tabular}{|l|l|c|c|c|c|}
\hline \multirow{3}{*}{ Locations } & \multirow{2}{*}{$\begin{array}{l}\text { Data recording } \\
\text { time (Month) }\end{array}$} & \multicolumn{4}{|c|}{ Leaf spot } \\
\cline { 3 - 6 } & & \multicolumn{2}{|c|}{$2010-2011$} & \multicolumn{2}{c|}{$2011-2012$} \\
\cline { 2 - 6 } & Incidence (\%) & Severity (\%) & Incidence (\%) & Severity (\%) \\
\hline \multirow{5}{*}{ Jessore } & July & $34.66 \mathrm{~g}$ & $25.96 \mathrm{~cd}$ & $27.90 \mathrm{~b}$ & 25.66 \\
\cline { 2 - 6 } & October & $57.30 \mathrm{c}$ & $31.76 \mathrm{bc}$ & $33.95 \mathrm{~b}$ & 27.67 \\
\cline { 2 - 6 } & January & $26.33 \mathrm{j}$ & $24.42 \mathrm{~cd}$ & $26.59 \mathrm{~b}$ & 24.12 \\
\cline { 2 - 6 } & April & $36.13 \mathrm{~g}$ & $30.74 \mathrm{bc}$ & $30.58 \mathrm{~b}$ & 27.13 \\
\hline \multirow{5}{*}{ Fhenaidah } & July & $45.92 \mathrm{e}$ & $27.96 \mathrm{~cd}$ & $34.91 \mathrm{~b}$ & 24.53 \\
\cline { 2 - 6 } & October & $53.05 \mathrm{~d}$ & $31.44 \mathrm{bc}$ & $36.78 \mathrm{~b}$ & 24.45 \\
\cline { 2 - 6 } & January & $29.04 \mathrm{i}$ & $24.98 \mathrm{~cd}$ & $24.89 \mathrm{~b}$ & 22.63 \\
\cline { 2 - 6 } & April & $47.08 \mathrm{e}$ & $29.46 \mathrm{bc}$ & $35.43 \mathrm{~b}$ & 25.45 \\
\hline & July & $43.73 \mathrm{f}$ & $19.60 \mathrm{~d}$ & $35.70 \mathrm{~b}$ & 17.37 \\
\cline { 2 - 6 } & October & $80.36 \mathrm{a}$ & $40.67 \mathrm{a}$ & $74.35 \mathrm{a}$ & 27.20 \\
\cline { 2 - 6 } & January & $31.88 \mathrm{~h}$ & $18.44 \mathrm{~d}$ & $25.97 \mathrm{~b}$ & 15.73 \\
\cline { 2 - 6 } & April & $75.16 \mathrm{~b}$ & $37.66 \mathrm{ab}$ & $60.45 \mathrm{a}$ & 20.97 \\
\hline CV (\%) & & 12.61 & 7.56 & 9.35 & 7.18 \\
\hline
\end{tabular}

In a column, figures having same letter (s) do not differ statistically at $5 \%$ level of significance by DMRT

In 2010-2011, the highest temperature prevailed from March to May, $\left(29.5^{\circ} \mathrm{C}\right)$, June was transitional period $\left(29.7^{\circ} \mathrm{C}\right)$ and an equable temperature $29.4^{\circ} \mathrm{C}$ prevailed from July to September. A fall in temperature was observed from October $\left(28.05^{\circ} \mathrm{C}\right)$ to the end of December $\left(18.4^{\circ} \mathrm{C}\right)$ and the coolest period prevailed during January and February $\left(18.3^{\circ} \mathrm{C}\right)$ as shown in (Fig. 1). About $80 \%$ annual rainfalls occurred during the monsoon, (late May to mid-October). Total amounts of rainfall in the locations Jessore, Jhenaidah and Faridpur were $1380 \mathrm{~mm}, 1388 \mathrm{~mm}$ and $1409 \mathrm{~mm}$, respectively. Slight rain was recorded in January, March and April were the least humid months, while the average relative humidity ranged from 69-78 \%, 69-77 \% and 66-78 \% in Jessore, Jhenaidah and Faridpur, respectively. The relative humidity during June to October was above $80 \%$ and during November to February was $77 \%$, $77 \%$ and $75 \%$ in Jessore, Jhenaidah and Faridpur, respectively. In 2011-2012, the weather parameters showed the similar trend as previous year. Based on the analysis of the climatic variations, four disease recording times were selected to observe the effect of weather on the incidence and severity of seedling diseases of coconut. In 2010-2011, the lowest incidence and severity of leaf spot disease of coconut (29.08 and $24.11 \%$, respectively) were recorded in January at temperature, relative humidity and rainfall of $16.0^{\circ} \mathrm{C}, 77 \%$ and $00 \mathrm{~mm}$, respectively. On the other hand, the highest prevalence of incidence and severity were recorded $(63.57 \%$ and $39.47 \%$, respectively) in October at temperature, relative humidity and rainfall of $27.9^{\circ} \mathrm{C}, 82 \%$ and $122 \mathrm{~mm}$, respectively (Fig. 1). In 2010-2011 incidence and severity of leaf spot disease of coconut under three locations viz. Jessore, Jhenaidah and Faridpur varied from $38.60-57.78 \%$ and $22.75-34.81 \%$, respectively (Fig.2). Statistically the highest incidence and severity were recorded at Faridpur and the lowest at Jessore. In 2011-2012, the lowest incidence and severity of leaf spot disease of coconut ( 29.50 and $22.28 \%$, respectively) were recorded in January at temperature, relative humidity and rainfall of $17.9^{\circ} \mathrm{C}, 78.6 \%$ and $31 \mathrm{~mm}$, respectively (Fig. 3). On the other hand, the highest prevalence of incidence and severity were recorded (46.79\% and $25.28 \%$, respectively) in October at temperature, relative humidity and rainfall of $28.2{ }^{\circ} \mathrm{C}, 78.3 \%$ and $13 \mathrm{~mm}$, respectively. In 2011-2012 incidence and severity of leaf spot disease of coconut under three locations viz. Jessore, Jhenaidah and Faridpur varied from 29.76-49.12 \% and 20.32-39.15\%, respectively (Fig. 4). The lowest incidence and severity of leaf spot disease of coconut (29.76 and $20.32 \%)$ were recorded at Jessore and the highest prevalence of incidence and severity were recorded (49.12 \% and $26.15 \%)$ at Faridpur. 


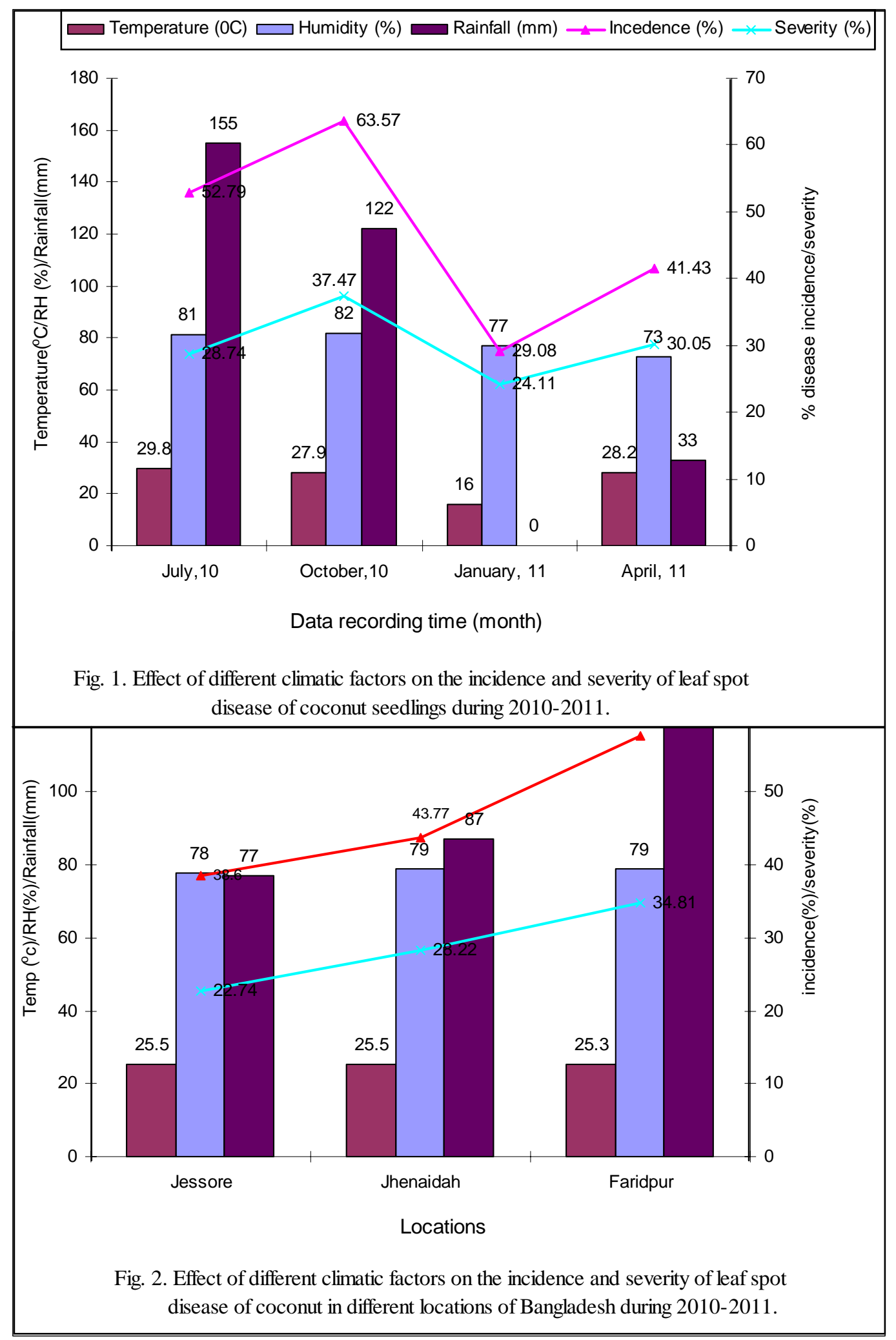




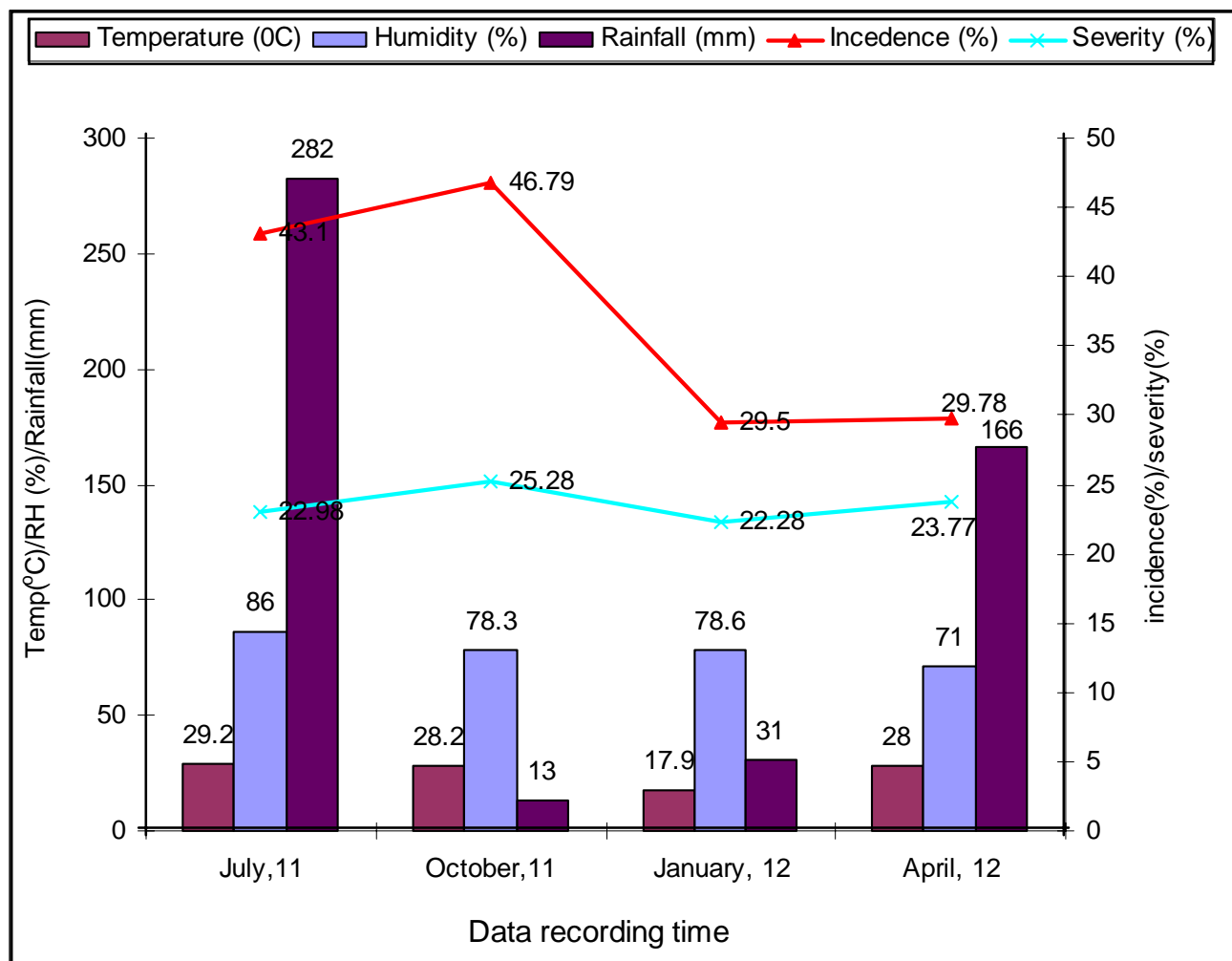

Fig. 3. Effect of different climatic factors on the incidence and severity of leaf spot disease of coconut seedlings during 2011-2012.

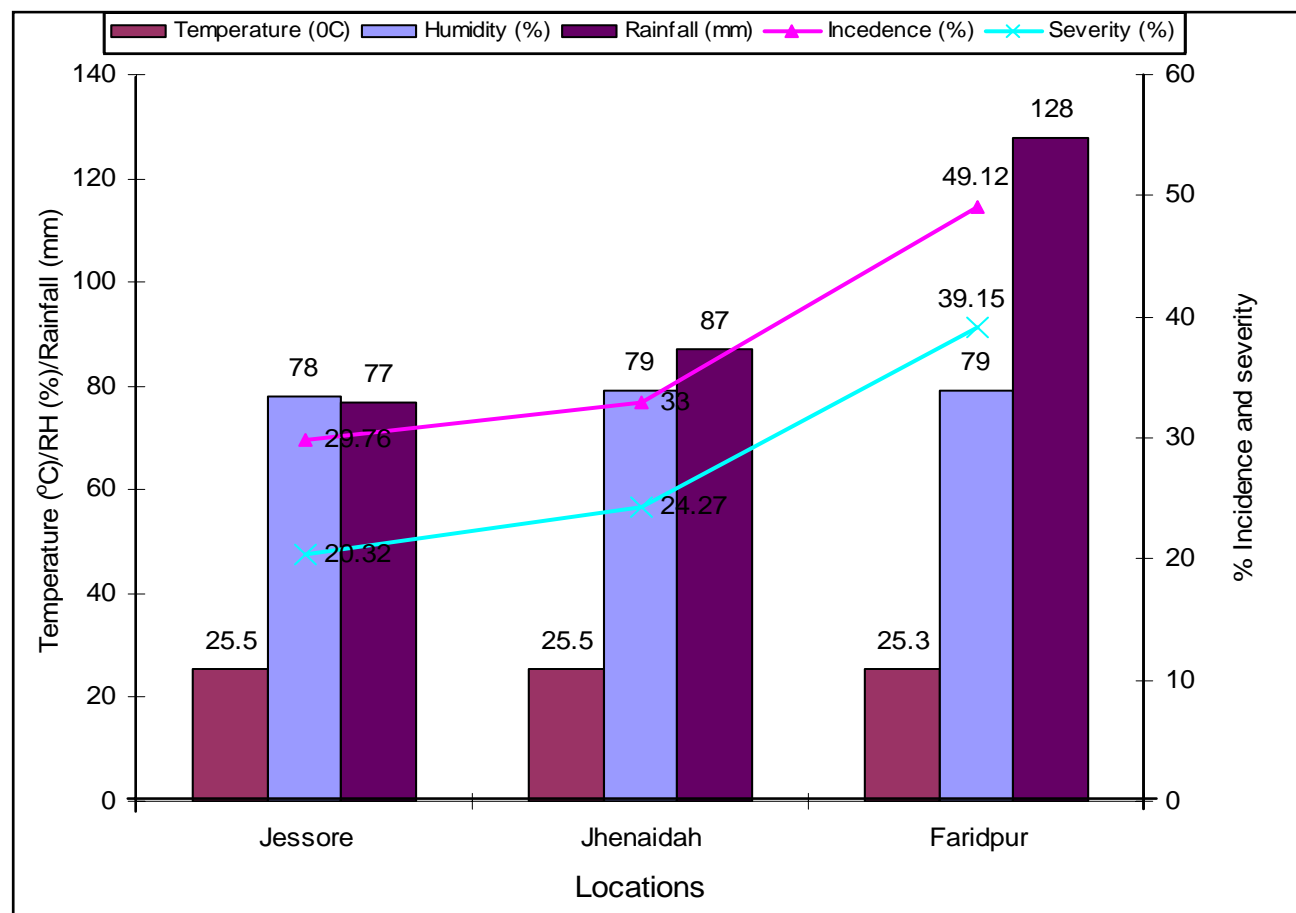

Fig. 4. Effect of different climatic factors on the incidence and severity of leaf spot disease of coconut in different locations of Bannladesh during 2011-2012. 
Correlation and linear regression analysis regarding relationship between different component of climatic factors (temperature, rainfall and relative humidity) and incidence as well as severity of leaf spot disease of coconut seedlings revealed that temperature was positively correlated with both incidence $(r=0.79)$ and severity (0.71) of leaf spot disease of coconut seedlings as shown in Table 2. Effect of temperature, relative humidity, rainfall, sun shine hour and leaf wetness on the incidence and severity of disease in different pathosystems have been reported by many researchers (Pinkerton et al., 1998; Mac Hardy et al., 2001; Mondal and Timmer, 2002 and Chowdhury and Hossain, 2011). Fitzell and Peak (1984) stated that the conidia of Colletotrichum gloeosporioides were produced in lesions on leaves, defoliated branch terminals, mummified inflorescence and flower bracts over a wide range of environmental conditions (10$30^{\circ} \mathrm{C},>95 \%$ relative humidity). Similar prevalence of leaf spot disease caused by Pestalotia palmarum was reported by Islam (2011). He also observed that coconut mainly suffered from leaf spot and bud rot disease in the nurseries. Pathak (1989) investigated the diseases of coconut and stated important diseases that include leaf rot, grey leaf spot and blight caused by Pestalotiopsis palmarum, and bud rot caused by Phytophthora palmivora. Harrison and Jones (2003) reported that coconut (Coccos nucifera) suffered from numerous diseases such as Ganoderma bud rot, lethal yellowing caused by (Phytoplasmas) red ring (Bursaphelenchus cocophilus) and basal stem rot (BSR) disease of coconut caused by (Ganoderma lucidum) was a major destructive disease limiting coconut production in some regions.

Table 2. Linear regression analysis of climatic factors (temperature, rainfall and relative humidity) with the incidence and severity of leaf spot disease of coconut seedlings

\begin{tabular}{|l|c|c|c|c|c|c|}
\hline \multirow{2}{*}{ Climatic factors } & \multicolumn{2}{|c|}{ Slope (b) } & \multicolumn{2}{c|}{$\begin{array}{c}\text { Coefficient of } \\
\text { determination }\left(\mathrm{R}^{2}\right)\end{array}$} & \multicolumn{2}{c|}{ Probability (P) } \\
\cline { 2 - 7 } & Incidence & Severity & Incidence & Severity & Incidence & Severity \\
\hline Temperature & 0.67 & 1.79 & 0.79 & 0.71 & 0.086 & 0.134 \\
\hline Rainfall & 0.003 & 0.006 & 0.05 & 0.04 & 0.81 & 0.83 \\
\hline Relative humidity & 0.062 & 0.35 & 0.03 & 0.04 & 0.88 & 0.87 \\
\hline
\end{tabular}

\section{Eco-friendly disease management trial}

Comparative effectiveness of BAU-Biofungicide either alone or in combination with chemical fungicides viz. Dithane M-45 and Bavistin were evaluated for controlling seedling disease of coconut. The leaf spot disease incidence was gradually decreased from October, 2010 to September, 2011 and the lowest was during August to September, 2011 (Table 3). Highest incidence of leaf spot (77.90\%) was recorded in untreated control and the lowest incidence $(42.00 \%)$ was recorded when BAU-Biofungicide was applied in soil @ $2 \%$ as well as foliar spray (2\%) that resulted the highest reduction of disease incidence by $46.08 \%$ over control. In 2011-2012, the lowest incidence of disease was observed in August to September, 2012 (Table 4). The highest incidence of leaf spot $(71.74 \%)$ was recorded in untreated control and the lowest incidence $(28.61 \%)$ was recorded when BAU-Biofungicide was applied in soil @ $2 \%$ and Bavistin as foliar spray @ $0.2 \%$ that resulted the highest reduction of leaf spot disease incidence by $60.12 \%$ over control.

The highest severity (31.27-45.96 \%) of leaf spot disease was found in October, 2010 and it was decreased in the following months up to May, 2011 and remained almost static from April, 2011 to June, 2011 (Table 5). In June, the severity was the lowest and in August, the severity was little higher than in the previous months. In case of untreated control, disease severity increased gradually from October, 2010 and the highest severity (47.89\%) was observed in August, 2011 and then it suddenly decreased up to $40.36 \%$ in the month of September, 2011. The fluctuation of disease severity might be due to environmental factors which have been supported by Chowdhury (2009). The highest leaf spot severity (44.56 \%) was observed in untreated control and the lowest severity $(19.93 \%)$ was observed in BAUBiofungicide was applied in soil @ $2 \%$ and Bavistin as foliar spray @ $0.2 \%$ which resulted the highest reduction (55.23\%) of disease severity over control. Results of the present investigation reveal that BAUBiofungicide is effective for controlling leaf spot of coconut. Among the chemicals Bavistin (0.2 \%) as foliar spray was also found good when incorporated with BAU-Biofungicide as soil drench for controlling coconut disease. Similar findings have also been supported by Chowdhury (2009), Hossain (2011), Akter et al. (2011) and Hossain et al. (2011). 
Table 3. Effect of different management practices on the incidence of leaf spot disease of coconut seedlings during the growing period of October 2010 to September 2011

\begin{tabular}{|c|c|c|c|c|c|c|c|c|c|c|c|c|c|c|}
\hline \multirow{2}{*}{ 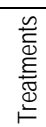 } & \multicolumn{14}{|c|}{ \% disease incidence } \\
\hline & $\begin{array}{l}\text { October } \\
2010\end{array}$ & \begin{tabular}{|c} 
November \\
2010
\end{tabular} & $\begin{array}{c}\text { December } \\
2010\end{array}$ & $\begin{array}{c}\text { January } \\
2011\end{array}$ & $\begin{array}{c}\text { February } \\
2011\end{array}$ & $\begin{array}{l}\text { March } \\
2011\end{array}$ & $\begin{array}{l}\text { April } \\
2011\end{array}$ & \begin{tabular}{|c|} 
May \\
2011
\end{tabular} & \begin{tabular}{|l} 
June \\
2011
\end{tabular} & $\begin{array}{l}\text { July } \\
2011\end{array}$ & $\begin{array}{c}\text { August } \\
2011\end{array}$ & \begin{tabular}{|c} 
September \\
2011
\end{tabular} & Mean & $\begin{array}{c}\% \\
\text { reduction } \\
\text { over control }\end{array}$ \\
\hline $\mathrm{T}_{1}$ & $50.14 \mathrm{bc}$ & $50.16 \mathrm{bc}$ & $46.82 \mathrm{bc}$ & $38.50 \mathrm{~cd}$ & $58.33 \mathrm{bc}$ & $57.93 \mathrm{~b}$ & $67.24 a$ & $69.72 a b$ & $51.85 \mathrm{c}$ & $66.67 \mathrm{ab}$ & $41.95 b$ & $45.39 b c$ & $53.73 \mathrm{bc}$ & 31.03 \\
\hline$\overline{T_{2}}$ & $44.45 \mathrm{~cd}$ & $44.44 \mathrm{~cd}$ & $41.11 \mathrm{~cd}$ & $40.78 \mathrm{c}$ & 45.55de & $46.89 \mathrm{~b}$ & $61.11 \mathrm{ab}$ & $65.95 a b$ & $46.54 \mathrm{bc}$ & $52.50 \mathrm{bc}$ & $36.47 \mathrm{bc}$ & $41.90 \mathrm{~cd}$ & $47.31 \mathrm{~cd}$ & 39.27 \\
\hline $\mathrm{T}_{3}$ & $40.00 \mathrm{~d}$ & $39.33 d$ & $33.33 d$ & $32.15 d$ & $45.67 \mathrm{de}$ & $47.62 \mathrm{~b}$ & $51.67 \mathrm{~b}$ & $53.33 \mathrm{bc}$ & $43.33 \mathrm{c}$ & $50.00 \mathrm{bc}$ & $31.66 \mathrm{bc}$ & $35.95 d$ & 42.00de & 46.08 \\
\hline $\mathrm{T}_{4}$ & 46.19cd & $45.02 \mathrm{~cd}$ & $43.14 \mathrm{c}$ & $41.00 \mathrm{c}$ & $46.67 \mathrm{~cd}$ & $53.33 \mathrm{~b}$ & $61.67 \mathrm{ab}$ & $52.38 \mathrm{bc}$ & $52.22 \mathrm{bc}$ & $53.33 \mathrm{bc}$ & $20.83 d$ & $21.67 \mathrm{~g}$ & $44.79 \mathrm{cde}$ & 42.50 \\
\hline$T_{5}$ & $43.49 \mathrm{~cd}$ & $41.16 \mathrm{~cd}$ & $46.67 \mathrm{bc}$ & $44.53 \mathrm{bc}$ & $48.89 \mathrm{~cd}$ & $49.05 b$ & $60.47 a b$ & $60.31 \mathrm{abc}$ & $49.00 \mathrm{bc}$ & $45.83 \mathrm{c}$ & $24.07 \mathrm{~cd}$ & $25.38 f g$ & $44.90 \mathrm{cde}$ & 42.36 \\
\hline$T_{6}$ & $39.05 d$ & $38.05 d$ & $40.00 \mathrm{~cd}$ & $33.33 \mathrm{~d}$ & $39.25 \mathrm{e}$ & $50.79 \mathrm{~b}$ & $49.05 \mathrm{~b}$ & $42.38 \mathrm{c}$ & $40.47 \mathrm{c}$ & $38.25 \mathrm{c}$ & $21.56 \mathrm{~d}$ & 27.31ef & $38.29 \mathrm{e}$ & 50.85 \\
\hline $\mathrm{T}_{7}$ & $73.89 a$ & $78.33 a$ & $80.24 a$ & $73.60 \mathrm{a}$ & $90.00 \mathrm{a}$ & $95.24 a$ & $86.03 a$ & $87.81 \mathrm{a}$ & $70.55 a$ & $73.67 \mathrm{a}$ & $65.20 \mathrm{a}$ & $60.23 a$ & $77.90 a$ & \\
\hline $\begin{array}{l}\mathrm{CV} \\
(\%)\end{array}$ & 10.59 & 12.74 & 9.20 & 11.40 & 9.97 & 13.45 & 10.78 & 12.60 & 13.35 & 11.40 & 9.21 & 10.03 & 7.83 & \\
\hline
\end{tabular}

Data represent the mean values of 3 replications; each replication was derived from 15 plants per treatments; in a column figures having similar letter(s) do not differ statistically at $5 \%$ level of significance by DMRT

$\mathrm{T}_{1}=$ Soil drenching with BAU-Biofungicide (2\%)

$\mathrm{T}_{2}=\mathrm{BAU}-$ Biofungicide as foliar spray $(2 \%)$

$\mathrm{T}_{3}=$ Soil drenching with BAU-Biofungicide (2\%) plus foliar spray (2\%)

$\mathrm{T}_{4}=$ Bavistin spray $(0.2 \%)$

$\mathrm{T}_{5}=$ Dithane $\mathrm{M}-45$ spray $(0.2 \%)$

$\mathrm{T}_{6}=$ Soil drenching with BAU-Biofungicide (2\%) plus Bavistin spray (0.2\%)

$\mathrm{T}_{7}=$ Control (Untreated)

In 2011-2012, the highest severity (9.16-47.84 \%) was found in October, 2011 and it was decreased in the following months up to September, 2012 and remained almost static from June, 2012 to September, 2012 (Table 6). In June, 2012 the severity was the lowest than in the previous months. In case of untreated control, disease severity increased gradually from October, 2011 and the highest severity (54.20 \%) was observed in January, 2012 and then it decreased up to $49.78 \%$ in the month of September, 2012. The highest leaf spot severity (50.59\%) was observed in untreated control and the lowest severity (5.69 \%) was observed in BAU-Biofungicide was applied in soil and Bavistin as foliar spray that resulted the highest reduction by $55.23 \%$ of disease severity over control. The lowest reduction (33.10) of disease severity over control was observed when BAU-Biofungicide applied in soil @ 2\%.

Table 4. Effect of different management practices on the incidence of leaf spot disease of coconut seedlings during the growing period of October 2011 to September 2012

\begin{tabular}{|c|c|c|c|c|c|c|c|c|c|c|c|c|c|c|}
\hline \multirow[b]{2}{*}{ 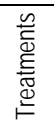 } & \multicolumn{14}{|c|}{$\%$ disease incidence } \\
\hline & $\begin{array}{c}\text { October } \\
2011\end{array}$ & $\begin{array}{c}\text { November } \\
2011\end{array}$ & $\begin{array}{c}\text { December } \\
2011\end{array}$ & $\begin{array}{c}\text { January } \\
2012\end{array}$ & $\begin{array}{c}\text { February } \\
2012\end{array}$ & $\begin{array}{l}\text { March } \\
2012\end{array}$ & $\begin{array}{l}\text { April } \\
2012\end{array}$ & $\begin{array}{l}\text { May } \\
2012\end{array}$ & \begin{tabular}{|l} 
June \\
2012
\end{tabular} & $\begin{array}{c}\text { July } \\
2012\end{array}$ & $\begin{array}{c}\text { August } \\
2012\end{array}$ & $\begin{array}{c}\text { September } \\
2012\end{array}$ & Mean & $\begin{array}{c}\% \\
\text { reduction } \\
\text { over control }\end{array}$ \\
\hline $\mathrm{T}_{1}$ & $43.91 b c$ & $44.52 b c$ & $40.28 \mathrm{~b}$ & $40.28 \mathrm{bc}$ & $53.31 \mathrm{~cd}$ & $55.55 \mathrm{c}$ & $53.17 \mathrm{bc}$ & $40.73 \mathrm{~cd}$ & $46.50 \mathrm{bc}$ & $44.11 b$ & $38.89 \mathrm{~b}$ & $29.52 b c$ & $44.23 b c$ & 38.35 \\
\hline $\mathrm{T}_{2}$ & $38.72 \mathrm{c}$ & $42.06 \mathrm{c}$ & $41.74 b$ & $36.50 \mathrm{c}$ & 43.53de & $49.05 \mathrm{~cd}$ & $45.40 \mathrm{~cd}$ & $33.68 \mathrm{e}$ & $29.52 \mathrm{e}$ & $30.16 \mathrm{c}$ & $30.16 \mathrm{bc}$ & $25.81 \mathrm{bc}$ & $37.19 \mathrm{~cd}$ & 48.16 \\
\hline$T_{3}$ & $37.30 \mathrm{c}$ & $37.30 \mathrm{c}$ & $34.08 \mathrm{bc}$ & $33.31 \mathrm{c}$ & $35.39 f$ & $42.06 \mathrm{~d}$ & $34.72 \mathrm{~d}$ & $35.71 d$ & $26.22 \mathrm{e}$ & $26.97 \mathrm{c}$ & $26.19 \mathrm{bc}$ & $17.87 \mathrm{bc}$ & $32.26 \mathrm{de}$ & 55.03 \\
\hline$T_{4}$ & $19.44 \mathrm{e}$ & $20.63 d$ & $30.95 b c$ & $35.12 \mathrm{c}$ & $58.72 \mathrm{c}$ & $56.55 \mathrm{c}$ & $55.59 \mathrm{bc}$ & 43.81cd & $41.11 \mathrm{c}$ & $36.50 \mathrm{bc}$ & $34.92 \mathrm{~b}$ & $31.14 b$ & $38.71 \mathrm{~cd}$ & 46.04 \\
\hline$T_{5}$ & $27.58 \mathrm{~d}$ & $19.05 \mathrm{e}$ & $35.65 \mathrm{bc}$ & $37.50 \mathrm{c}$ & $62.10 \mathrm{bc}$ & $59.52 b c$ & $61.74 b$ & $47.01 \mathrm{bc}$ & 30.95de & $37.89 \mathrm{bc}$ & $37.90 \mathrm{~b}$ & $31.74 \mathrm{~b}$ & $40.80 \mathrm{c}$ & 43.13 \\
\hline$T_{6}$ & $27.31 d$ & $20.83 d$ & $19.91 \mathrm{c}$ & $22.62 \mathrm{~d}$ & 42.06ef & $39.06 \mathrm{~d}$ & 41.11cd & $37.06 \mathrm{~d}$ & $29.10 \mathrm{e}$ & $30.74 \mathrm{c}$ & $17.49 \mathrm{c}$ & $16.05 \mathrm{c}$ & $28.61 \mathrm{e}$ & 60.12 \\
\hline $\mathrm{T}_{7}$ & $56.41 a$ & $56.50 \mathrm{a}$ & $68.05 a$ & $72.22 \mathrm{a}$ & $90.47 a$ & $90.47 a$ & $82.22 a$ & $79.00 \mathrm{a}$ & $64.44 a$ & $68.89 a$ & $68.89 a$ & $63.33 a$ & $71.74 a$ & \\
\hline $\begin{array}{c}\text { CV } \\
(\%)\end{array}$ & 8.43 & 8.08 & 8.50 & 9.56 & 8.70 & 6.66 & 7.35 & 9.22 & 7.48 & 8.95 & 6.97 & 8.09 & 7.03 & \\
\hline
\end{tabular}

Data represent the mean values of 3 replications; each replication was derived from 15 plants per treatments; in a column figures having similar letter(s) do not differ statistically at $5 \%$ level of significance by DMRT

$\mathrm{T}_{1}=$ Soil drenching with BAU-Biofungicide (2\%)

$\mathrm{T}_{2}=$ BAU-Biofungicide as foliar spray (2\%)

$\mathrm{T}_{3}=$ Soil drenching with BAU-Biofungicide (2\%) plus foliar spray (2\%)

$\mathrm{T}_{4}=$ Bavistin spray $(0.2 \%)$

$\mathrm{T}_{5}=$ Dithane $\mathrm{M}-45$ spray $(0.2 \%)$

$\mathrm{T}_{6}=$ Soil drenching with BAU-Biofungicide (2\%) plus Bavistin spray $(0.2 \%)$

$\mathrm{T}_{7}=$ Control (Untreated) 
Table 5. Effect of different management practices on the severity of leaf spot disease of coconut seedlings during the growing period of October 2010 to September 2011

\begin{tabular}{|c|c|c|c|c|c|c|c|c|c|c|c|c|c|c|}
\hline \multirow[b]{2}{*}{ 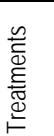 } & \multicolumn{14}{|c|}{$\%$ disease severity } \\
\hline & $\begin{array}{c}\text { October } \\
2010\end{array}$ & $\begin{array}{l}\text { November } \\
2010\end{array}$ & $\begin{array}{c}\text { December } \\
2010\end{array}$ & $\begin{array}{c}\text { January } \\
2011\end{array}$ & $\begin{array}{c}\text { February } \\
2011\end{array}$ & $\begin{array}{l}\text { March } \\
2011\end{array}$ & $\begin{array}{l}\text { April } \\
2011\end{array}$ & $\begin{array}{l}\text { May } \\
2011\end{array}$ & $\begin{array}{l}\text { June } \\
2011\end{array}$ & $\begin{array}{l}\text { July } \\
2011\end{array}$ & $\begin{array}{c}\text { August } \\
2011\end{array}$ & \begin{tabular}{|c|} 
September \\
2011
\end{tabular} & Mean & $\begin{array}{c}\% \% \\
\text { reduction } \\
\text { over control }\end{array}$ \\
\hline $\mathrm{T}_{1}$ & $35.16 c$ & $35.13 b$ & $32.65 b$ & $30.74 b$ & $35.94 \mathrm{bc}$ & $35.49 b c$ & $27.28 \mathrm{bc}$ & $23.89 \mathrm{bc}$ & $25.09 b$ & $24.90 \mathrm{~b}$ & $26.06 \mathrm{~b}$ & $25.40 \mathrm{~b}$ & $29.81 b$ & 33.10 \\
\hline $\mathrm{T}_{2}$ & $31.82 \mathrm{C}$ & $29.46 \mathrm{bc}$ & $28.22 \mathrm{bc}$ & $27.79 \mathrm{~b}$ & $32.11 \mathrm{~cd}$ & $32.02 \mathrm{~cd}$ & $22.95 \mathrm{~cd}$ & $22.64 \mathrm{c}$ & 15.97de & 15.26de & 15.82de & $14.06 \mathrm{~cd}$ & $24.01 \mathrm{~cd}$ & 46.12 \\
\hline$T_{3}$ & $31.27 \mathrm{c}$ & $26.44 \mathrm{c}$ & $24.09 \mathrm{~cd}$ & $23.33 \mathrm{bc}$ & $23.46 \mathrm{e}$ & $25.69 \mathrm{e}$ & $20.59 \mathrm{de}$ & $21.54 \mathrm{c}$ & $15.18 \mathrm{e}$ & $13.08 \mathrm{e}$ & $12.42 f$ & $8.21 f$ & $20.44 d$ & 54.13 \\
\hline $\mathrm{T}_{4}$ & $35.78 c$ & $31.33 b c$ & $24.48 \mathrm{~cd}$ & $23.71 b c$ & 27.66de & 27.04de & $25.17 \mathrm{~cd}$ & $22.36 c$ & 17.15de & $13.64 \mathrm{e}$ & $12.21 \mathrm{f}$ & $9.41 \mathrm{f}$ & $22.50 \mathrm{~d}$ & 49.51 \\
\hline$T_{5}$ & $35.90 \mathrm{c}$ & $28.14 \mathrm{c}$ & $16.57 \mathrm{~d}$ & $21.94 b c$ & $28.89 d$ & $28.14 d$ & $25.80 \mathrm{c}$ & $23.66 \mathrm{c}$ & $19.06 \mathrm{~cd}$ & $18.06 \mathrm{~cd}$ & $17.55 \mathrm{~cd}$ & $13.42 d$ & $23.09 \mathrm{~d}$ & 48.18 \\
\hline$T_{6}$ & $36.64 b c$ & $29.70 b c$ & $19.88 \mathrm{~cd}$ & $18.77 \mathrm{c}$ & $23.16 \mathrm{e}$ & $23.51 \mathrm{e}$ & $18.92 \mathrm{e}$ & $16.98 \mathrm{~d}$ & 15.99de & $12.95 \mathrm{e}$ & 13.10ef & $9.55 \mathrm{ef}$ & $19.93 d$ & 55.27 \\
\hline $\mathrm{T}_{7}$ & $45.96 a$ & $45.97 a$ & $46.90 \mathrm{a}$ & $47.70 \mathrm{a}$ & $47.84 a$ & $48.08 \mathrm{a}$ & $43.69 a$ & $42.33 a$ & $42.00 \mathrm{a}$ & $44.95 a$ & $47.89 a$ & $40.36 a$ & $44.56 \mathrm{a}$ & \\
\hline $\begin{array}{l}\text { CV } \\
(\%)\end{array}$ & 11.18 & 10.11 & 7.98 & 8.41 & 7.08 & 7.09 & 9.28 & 9.09 & 9.50 & 7.76 & 12.76 & 8.19 & 6.67 & \\
\hline
\end{tabular}

Data represent the mean values of 3 replications; each replication was derived from 15 plants per treatments; in a column figures having similar letter(s) do not differ statistically at $5 \%$ level of significance by DMRT

$\mathrm{T}_{1}=$ Soil drenching with BAU-Biofungicide (2\%)

$\mathrm{T}_{2}=\mathrm{BAU}-$ Biofungicide as foliar spray $(2 \%)$

$\mathrm{T}_{3}=$ Soil drenching with BAU-Biofungicide (2\%) plus foliar spray (2\%)

$\mathrm{T}_{4}=$ Bavistin spray $(0.2 \%)$

$\mathrm{T}_{5}=$ Dithane $\mathrm{M}-45$ spray $(0.2 \%)$

$\mathrm{T}_{6}=$ Soil drenching with BAU-Biofungicide $(2 \%)$ plus Bavistin spray $(0.2 \%)$

$\mathrm{T}_{7}=$ Control (Untreated)

Table 6. Effect of different management practices on the severity of leaf spot disease of coconut seedlings during the growing period of October 2011 to September 2012

\begin{tabular}{|c|c|c|c|c|c|c|c|c|c|c|c|c|c|c|}
\hline \multirow{2}{*}{ 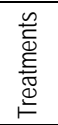 } & \multicolumn{14}{|c|}{$\%$ disease severity } \\
\hline & $\begin{array}{l}\text { October } \\
2011\end{array}$ & $\begin{array}{c}\text { November } \\
2011\end{array}$ & $\begin{array}{c}\text { December } \\
2011\end{array}$ & $\begin{array}{c}\text { January } \\
2012\end{array}$ & $\begin{array}{c}\text { February } \\
2012\end{array}$ & $\begin{array}{l}\text { March } \\
2012\end{array}$ & $\begin{array}{l}\text { April } \\
2012\end{array}$ & $\begin{array}{l}\text { May } \\
2012\end{array}$ & $\begin{array}{l}\text { June } \\
2012\end{array}$ & $\begin{array}{l}\text { July } \\
2012\end{array}$ & $\begin{array}{l}\text { August } \\
2012\end{array}$ & \begin{tabular}{|c|} 
September \\
2012
\end{tabular} & Mean & $\begin{array}{c}\% \\
\text { reduction } \\
\text { over control }\end{array}$ \\
\hline $\mathrm{T}_{1}$ & $28.56 \mathrm{~b}$ & $27.60 \mathrm{~b}$ & $16.10 \mathrm{~b}$ & $15.92 b$ & $14.77 \mathrm{~b}$ & $14.30 \mathrm{~b}$ & $13.50 \mathrm{~b}$ & $14.15 b$ & $11.40 \mathrm{~b}$ & $11.24 b$ & $11.99 \mathrm{~b}$ & $11.82 \mathrm{~b}$ & $15.95 b$ & \begin{tabular}{|l|}
68.47 \\
\end{tabular} \\
\hline $\mathrm{T}_{2}$ & $16.08 \mathrm{c}$ & $13.90 \mathrm{c}$ & $10.18 \mathrm{c}$ & $8.48 \mathrm{de}$ & 6.44ef & 6.44ef & $6.71 \mathrm{~d}$ & $5.10 \mathrm{~d}$ & $3.24 \mathrm{e}$ & $3.31 \mathrm{e}$ & $3.66 \mathrm{de}$ & 3.60de & $7.26 \mathrm{~d}$ & 85.65 \\
\hline$T_{3}$ & 12.55de & $13.75 \mathrm{~cd}$ & $6.47 \mathrm{e}$ & $5.33 \mathrm{~g}$ & $6.30 \mathrm{ef}$ & $6.26 \mathrm{ef}$ & $3.59 \mathrm{e}$ & $2.63 \mathrm{e}$ & $2.22 f$ & $2.26 f$ & $3.41 \mathrm{e}$ & $3.53 \mathrm{e}$ & $5.69 \mathrm{e}$ & 88.75 \\
\hline $\mathrm{T}_{4}$ & 11.75ef & 12.37de & $9.91 \mathrm{c}$ & 6.72ef & 7.66de & 7.49de & $7.07 \mathrm{~cd}$ & $6.57 \mathrm{~cd}$ & $5.66 \mathrm{~cd}$ & $5.35 \mathrm{~cd}$ & $4.34 \mathrm{~d}$ & $4.19 \mathrm{~d}$ & $7.42 \mathrm{~d}$ & 85.33 \\
\hline$T_{5}$ & $12.36 \mathrm{e}$ & 12.50d & $10.78 \mathrm{c}$ & $9.03 \mathrm{~cd}$ & $8.83 \mathrm{c}$ & $8.83 \mathrm{c}$ & $6.93 \mathrm{~d}$ & $6.60 \mathrm{~cd}$ & $5.64 \mathrm{~cd}$ & $5.31 \mathrm{~cd}$ & $4.65 \mathrm{~cd}$ & $4.68 \mathrm{~cd}$ & $8.01 \mathrm{c}$ & 84.17 \\
\hline$T_{6}$ & $9.16 f$ & $10.66 \mathrm{e}$ & $7.69 \mathrm{de}$ & $6.24 f g$ & $6.11 \mathrm{f}$ & $6.89 \mathrm{e}$ & $6.05 d$ & $6.05 d$ & $4.68 \mathrm{~d}$ & $4.65 d$ & $3.28 \mathrm{e}$ & $3.13 \mathrm{e}$ & $6.22 \mathrm{de}$ & 87.71 \\
\hline $\mathrm{T}_{7}$ & $47.84 a$ & $44.85 a$ & $44.75 a$ & $54.20 a$ & $52.47 a$ & $53.42 \mathrm{a}$ & $53.36 \mathrm{a}$ & $51.37 \mathrm{a}$ & $51.76 \mathrm{a}$ & $52.61 \mathrm{a}$ & $50.66 \mathrm{a}$ & $49.78 \mathrm{a}$ & $50.59 a$ & \\
\hline $\begin{array}{l}\mathrm{CV} \\
(\%)\end{array}$ & 10.18 & 8.06 & 6.79 & 9.62 & 7.15 & 7.88 & 6.94 & 9.88 & 11.05 & 9.78 & 11.89 & 7.91 & 7.11 & \\
\hline
\end{tabular}

Data represent the mean values of 3 replications; each replication was derived from 15 plants per treatments; in a column figures having similar letter(s) do not differ statistically at $5 \%$ level of significance by DMRT

$\mathrm{T}_{1}=$ Soil drenching with BAU-Biofungicide (2 \%)

$\mathrm{T}_{2}=\mathrm{BAU}-$ Biofungicide as foliar spray $(2 \%)$

$\mathrm{T}_{3}=$ Soil drenching with BAU-Biofungicide (2\%) plus foliar spray (2\%)

$\mathrm{T}_{4}=$ Bavistin spray $(0.2 \%)$

$\mathrm{T}_{5}=$ Dithane $\mathrm{M}-45$ spray $(0.2 \%)$

$\mathrm{T}_{6}=$ Soil drenching with BAU-Biofungicide (2\%) plus Bavistin spray (0.2\%)

$\mathrm{T}_{7}=$ Control (Untreated)

Application of treatments resulted gradual decrease of incidence in the months of August, 2011 to September, 2012. This might be due to growth and flashes of new leaves which were not attacked by the pathogen. Coconut main growth flushes appeared once in a year from July to September. The fluctuation of disease incidence might be due to environmental factors which have been supported by Chowdhury (2009). The highest reduction of disease incidence by $60.12 \%$ was observed when BAU-Biofungicide was applied in soil @ $2 \%$ and Bavistin as foliar spray @ $0.2 \%$ over control. The lowest severity of the disease was observed in September 2011 and it became almost static in October 2011 to November 2011 and then it was gradually decreased in the following months up to September 2012. This might be due to use of eco-friendly management treatments in a regular interval. Results of the present investigation reveal that BAU-Biofungicide was effective for controlling leaf spot of coconut. Among the 
chemicals Bavistin (0.2\%) as foliar spray was also found good when incorporated with BAU-Biofungicide as soil drench for controlling coconut disease. Similar findings have also been supported by Chowdhury (2009), Hossain (2011), Akter et al. (2011) and Hossain et al. (2011). From the study it may be concluded that leaf spot disease of coconut was influenced by weather factors. Out of the control measures employed, BAU-Biofungicide was found superior for controlling the diseases of coconut. BAUBiofungicide (2\%) either alone or in combination with Bavistin (0.2\%) was found as an excellent biocontrol means for controlling leaf spot disease of coconut.

\section{Acknowledgements}

The present research was conducted under the project "Surveillance of seedling diseases of some important fruit species in Bangladesh with molecular characterization of pathogens and eco-friendly model development for their management" financed by PIU-BARC (NATP phase-1), Bangladesh Agricultural Research Council, Farm gate, Dhaka-1215.

\section{References}

BBS, 2008. Bangladesh Bureau of Statistics, 2008. Yearbook of Agricultural Statistics of Bangladesh. Bangladesh Bureau of Statistics, Planning division, Ministry of Planning, Government of the People's Republic of Bangladesh, Dhaka, Bangladesh.

Chowdhury, M.S.M. 2009. Seed and seedling diseases of some selected fruits of Bangladesh. Ph. D. Thesis. Department of Plant Pathology, Bangladesh Agricultural University, Mymensingh. pp. 97-124.

Chowdhury, M.S.M. and Hossain, I. 2011. Effects of temperature, rainfall and relative humidity on leaf spot of jackfruit seedling and its eco-friendly management. The Agriculturists 9 (1\&2): 126-136.

Fitzell, R.D. and Peak, C.M. 1984. The epidemiology of anthracnose disease of mango inoculum sources, spore production and disposal. Ann. App. Biol. 104: 53-59pp.

FRG, 2005. Fertilizer Recommendation Guide. 2005. Published by: The Bangladesh Agricultural Research Council, Farmgate, New Airport Road, Dhaka-1215.

Ghose, S. 2000. Bud rot of coconut. Diseases of plantation crops spices, betel vine and mulberry. 57-61.

Gomez, K.A. and Gomez, A.A. 1984. Statistical procedures for agricultural research. Int. Rice Res. Inst. John Wiley \& Sons, New York. Pp. 139-240.

HKI (Helen Keller International). 2005. NGO Gardening and Nutrition Education Surveillance Project (NGNESP). HKI NGNESP monitoring summery report of surveys. pp 14-19.

Hopkins, K.E. and McQuilken, M.P. 2000. Characteristics of Pestalotiopsis associated with hardy ornamental plants in the UK. European Journal of Plant Pathology, 106: 77-85.

Hossain, I. 2003. BAU-Biofungicide, Agricultural Technologies, BAURES, Bangladesh Agril. Univ. Mymensingh, Bangladesh. 18p.

Hossain, I. 2011. Nursery diseases of some selected fruit species in Bangladesh. Eco-friendly Plant Disease Management Laboratory, Department of Plant Pathology, Bangladesh Agricultural University, Mymensingh, Bangladesh, 24 pp.

Hossain, I., Naher, S. and Ahmad, M.U. 2011. Occurrence of nursery diseases of litchi in Bangladesh and efficacy of chemical fungicide and BAU-Biofungicide for their control. Bangladesh J. Plant Pathol. 27 (1\&2) : 1-7.

Islam, M.R. 2011. Studies on seedling disease of Jujube and Coconut in Jhenaidah and Jessore. M. S. thesis, Department of Plant Pathology, Bangladesh Agricultural University, Mymensingh. 1-44pp.

Johnston, P.R. 2000. The importance of phylogeny in understanding of host relationships within Colletotrichum. In: Prusky D, Dickman M. B. Freeman S, eds. Colletotrichum host specificity, Pathogenicity and host-pathogen interactions. St. Paul, Minnesota:APS Press. P 21-28.

Lo, C.T., Nelson, E.B. and Harman, G.E. 1996. Biological control of turf grass diseases with a rhizosphere competent strain Trichoderma harzianum. Plant Disease, 80: 736-741.

MacHardy, W.E., Gadoury, D.M. and Gessler, C. 2001. Parasitic and biological fitness of Venturia inaequalis: relationship to disease management strategies. Plant Disease, 85: 1036-1051.

Mariau, D. 2001. Diseases of tropical tree Crops. Oxford \& IBM Publishing Co.

Mondal, M.F. 2000. Production and Storage of Fruits (in Bangla). BAU Campus, Mymensingh-2002.pp.312.

Mondal, S.N. and Timmer, L.W. 2002. Environmental factors affecting pseudothecial development and ascospore production of Mycosphaerella citri, the causal pathogen of citrus greasy spot. Phytopathology, 92: 1267-1275.

Pathak, V.N. 1980. Diseases of fruit crops. Oxford IBH publishing Co. New Delhi. 12-22 pp. 
Pathak, V.N. 1989. Diseases of fruit crops. Oxford \& IBH Publishing Co. Pvt. Ltd. New Delhi, Bombay Calcutta, India. 249-250pp.

Pinkerton, J.N., Johnson, K.B., Stone, J.K. and Ivors, K.L. 1998. Factors affection the release of ascospores of Anisogramma anomala. Phytopathology, 88: 122-128.

Ploetz, R.C., Zentmyer, G.A., Nishijima, W.T., Rohrbach, K.G. and Ohr, H.D. 1998. Compendium of Tropical Fruit Diseases. APS Press. The American Phytopathological Society. pp. 34-44.

Rahim, M.A. 2009. Message from the president, Fruit Science Society of Bangladesh. In: International conference on quality seed and food security, 17-19 February 2009. Bangladesh Agricultural University, Mymensingh, Bangladesh.

Rai, V.R. and Mamatha, T. 2005. Seedling diseases of some important forest tree species and their management. In. Working papers of the Finnish Forest Research Institute, 11p.

Rawal, R.D. 1990. Fungal and bacterial diseases of fruit crops. A decade of research on diseases of horticultural crops under AICRIP (1980-1989). Presented at a group discussion of plant pathologists working in coordinated projects of horticulture, held at IIHR during June 14-15, 1990.

Akter, R., Hossain, I. and Islam, T. 2011. Management of nursery diseases of jackfruit. Bangladesh J. Environ. Sci. 21 (1) : $136-139$.

Russel, D.F. 1986. MSTAT-C package programme. Crop and Soil Science Department, Michigan State University, USA.

Singh, R.S. 1998. Plant Diseases. $7^{\text {th }}$ edition. Oxford and IBH Publishing Co.

Singh, S.J. 1996. Advance in Diseases of fruit crops in India. Kalyani Publisher. Ludhiana, New Delhi, India. Pp.197-199.

Sutton, T.B. 1981. Production and dispersal of ascospores and conidia by Physalospora obtuse and Botryosphaeria dothidea in apple orchards. Phytopathology, 71: 584-589. 